\title{
Benthic Diatom Motility in Estuarine Mudflats and Coastal Sands of the Atlantic Ocean Coast
}

\author{
Alyssa Thomson and Kalina Manoylov* \\ Department of Biological \& Environmental Sciences, Georgia College, Milledgeville, Georgia, 31061,
}

USA

Received: July 06, 2017; Accepted: July 17, 2017; Published: August 03, 2017

*Corresponding author: Kalina Manoylov, Department of Biological \& Environmental Sciences, Georgia College, Milledgeville, Georgia, 31061, USA, E-mail: kalina.manoylov@gcsu.edu

\begin{abstract}
Diatoms are known to dominate sediments of coastal microbial communities in estuaries, marshes, and beaches where their ecological role as primary producers is of great importance. In addition, the high diversity of species requires careful taxonomic and ecological evaluation. Loss of diatom dominance in coastal habitats can signal significant alteration of ecosystem services and can be used in management practices. With the current alterations of the Savannah River, due to the Savannah River Expansion Project, algae inhabiting the soft mud and sediment habitats found upstream in the estuary of the river are expected to be impacted significantly. Deepening and widening of the river will increase fine sediment load, which will intensify turbidity of the water and possibly cause extensive burial of the algal community. At low tide, many benthic diatoms possess the ability to migrate to the surface of the sediment where light enables photosynthesis. The distances traveled by diatoms and the timing of the movement remains largely unknown. In this study, algal communities were evaluated to the lowest taxonomic level. The algal community was dominated by biraphid diatoms capable of motility. Eleven benthic diatoms collected in the Savannah River estuary mudflats were documented and described including, Nitzschia brevissima, Cylindrotheca gracilis and Fallacia subforcipata. Artificial environments were recreated in a laboratory set-up to observe vertical migration of a biraphid diatom; Nitzschia closterium populations were covered with either fine sand and coarse sand sediments. Diatoms were stimulated to move upwards after exposure to continuous light for 24-72-120 hour intervals. Diatoms remained alive but did not migrate to the surface. This was potentially due to unnatural sediment packing and lack of environmental stimuli, like tides and sunlight.
\end{abstract}

Keywords: Coastal algal communities; Savannah River mudflat; Diatoms; Vertical migration;

\section{Introduction}

Species representing microphytobenthos have an important role in estuarine ecosystems, as they are known to contribute up to one-third of the total fixed carbon [1]. These organisms are also the main food source for invertebrates, fish, and birds in and along the estuary. Diverse diatom communities, which contribute to the majority population of microphytobenthos, are found in large quantities on the surface of intertidal sediments. Intertidal zones are characterized as the foreshore portion that is exposed to the atmosphere during low tide events and covered with water at high tide. These areas are dominated by pinnate diatoms that posses a characteristic feature, known as a raphe. A raphe system consists of two slits through each valve of the frustules. Those slits enable short mucilage threads to be released and hydrated in the external environment becoming sticky [2]. Motility is a useful adaptation for these organisms, especially in a highly fluctuating location like an estuary. Moving upwards in sediments allows reaching suitable environment quickly and efficiently [3]. Vertical migration is ecologically important because benthic algae produce biofilms as they move and their extracellular polymeric substances (EPS) have been associated with the stability of sediments. EPS acts as a natural protection against storm erosion and wave disturbance $[1,4]$. EPS also prevent and reduce dehydration of algal cells within coastal benthic communities [5].

The Savannah River is currently under construction, where the Army Corps of Engineers are conducting the Savannah Harbor Expansion Project [6]. This entails the deepening and widening of the estuary through dredging, which will essentially increase the sediment load upstream and downstream. Although other environmental factors can potentially affect the estuarine ecosystem, the effects of the increased sediment load were analyzed, focusing on the motile diatom communities' response to particle deposition. It has been proposed that benthic diatoms are particularly sensitive to an abundance of fine sediment loads, as those could hinder their ability to migrate [7]. Sediments increase the turbidity of a water system, which could lower light availability, and reduce the photosynthetic rate of algae. Logic systems produce excessive mobilization of fine sediments, which could have detrimental impacts on the primary producers [7].

Baseline data was collected in 2011, during pre-construction, whereas the community for this study has been exposed to the alterations in water clarity due to construction [8].This 
study concentrated one epipelic and epipsammic diatoms from the Savannah River, as they were reported as the dominant photosynthetic contributors of organic matter to the mudflats [8]. The effect of different sediment sizes and light quantity in relation to diatom vertical movement are largely unknown. Artificial environments were created within a laboratory setting to allow isolation of specific factors influencing diatom motility. It is expected that motile diatoms move faster towards the light in porous sandy sediments.

\section{Materials and Methods}

\section{Study Site}

Sampling was conducted at two sites (Figure 1). Site 1 was within the Savannah River Estuary at United States Geological Survey(USGS) site 2198920, located in Port Wentworth,
Georgia (Lat $32^{0} 09^{\prime} 57^{\prime \prime}$ Long $\left.81^{0} 09^{\prime} 14^{\prime \prime}\right)$. The site is located approximately $31 \mathrm{~km}$ north of the mouth of the river. Also, within Port Wentworth, the river is constantly monitored by USGS gagging station and data is publically available (https://nwis. waterdata.usgs.gov). Data from low tides is presented as positive values of cubic meters per second, while high tide data is given with negative values. Mud samples and physical characteristics from the estuary were collected at low tide from the shore (Figure $1 \mathrm{~b}-\mathrm{c})$.

Coarser sediment was collected from a sampling location within Jekyll Island (Site 2), which is a barrier island off the Atlantic coast of Georgia. The algal community was documented as physiologically active and moving through the sand to the surface at low tide (Figure 1d-e). Material from this site provided significantly different particle sizes for the experiment.
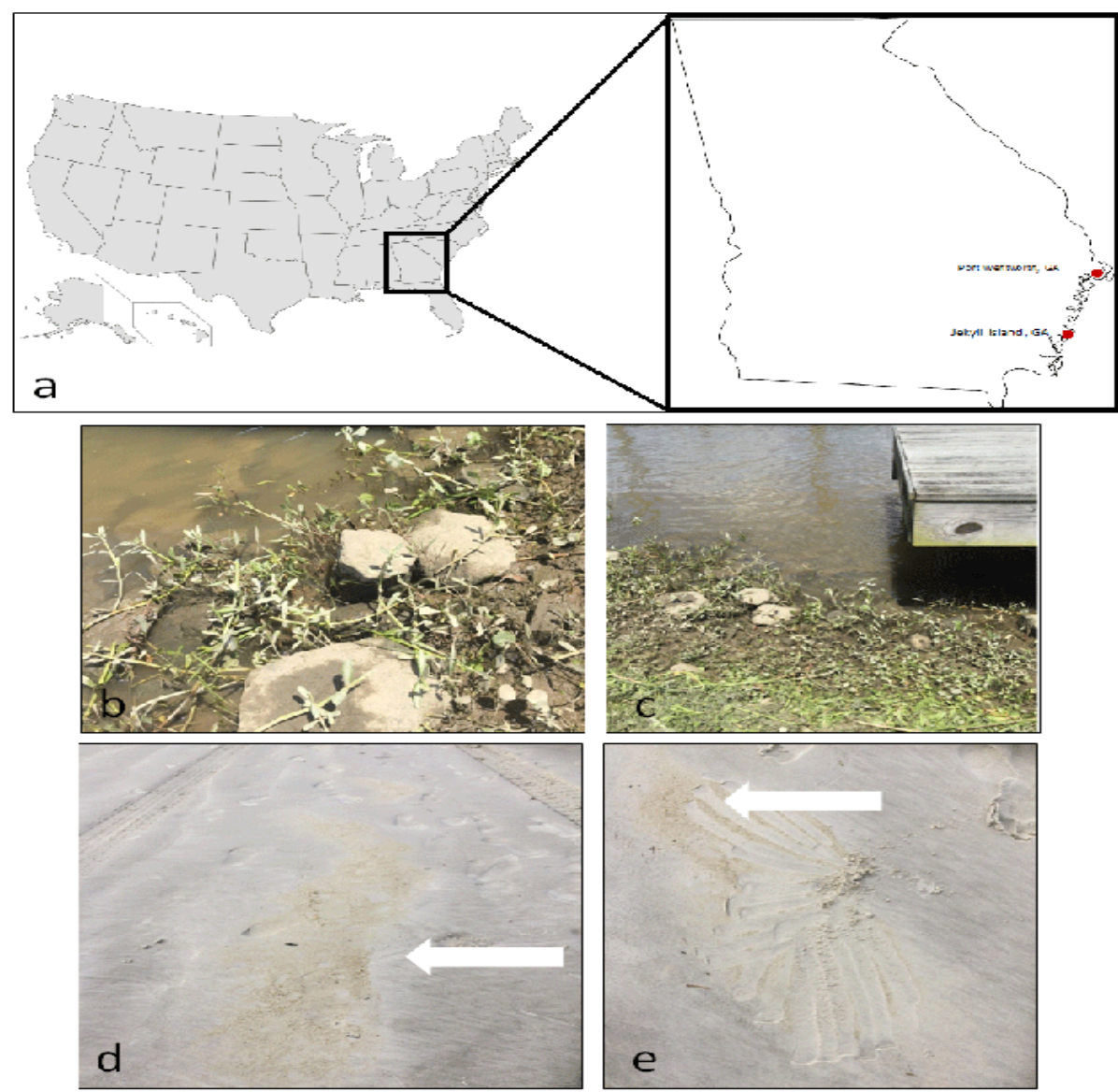

Figure 1: (a) Map of the United States emphasizing the state of Georgia. Study sites recognized by red circles on the coast of Georgia. (b-c) Field pictures from the Savannah River Estuary (Site 1) during low tide. (d-e) Field pictures from Jekyll Island (Site 2) during low tide; arrows to focus on evident yellow algal biofilm during sediment scraping.

\section{Sample Collection \& Field Equipment}

Mud samples were collected along with physicochemical measurements. Physicochemical measurements were taken using a Multi probe YSI 556 System (YSI Inc., Yellow Springs, Ohio) at the time of each collection within the water column closest to the exposed mudflat. Temperature, $\mathrm{pH}$, conductivity, and dissolved oxygen (DO) were measured. Triplicate YSI readings were obtained during both high and low tide events on December 18, 2016 (http://tides.mobilegeographics.com). Triplicate mud samples were scrapped at the top $1 \mathrm{~mm}$ surface where sunlight was present along the river's perimeter. All samples were collected following the APHA protocol [9]. There were no weather changes between the tide events. Conductivity 
was expected to increase significantly during high tide.

Sand sediment was collected during one sampling session in March 2017 at Site 2. The top 2mm of sand where high tide retreated (indicating low tide conditions) was scrapped to gather sand samples (Figure $1 \mathrm{e}$ ).

\section{Algal Community Composition}

Samples were scanned for diatoms that retained physiologically active chloroplasts at the time of collection and upon return in the lab. Light Microscope (LM) observations of the specimens were performed using a Leica DM2500 microscope with differential interference contrast optics and Leica DFC295 Camera attached to the microscope (Leica Microsystems, Wetzlar, Germany) at Georgia College and State University.

Approximately $10 \mathrm{~mL}$ of the subsamples from each triplicate were place in a $250 \mathrm{~mL}$ glass beaker to be put in a 1:3 ratio of Erschreiber's Medium and filtered seawater. The samples were then placed under growth lights, which were alternated (on/off) to stimulate day (12 hours) and night (12 hours) environments. The cultures were maintained under $75.0 \mu \mathrm{mol} \mathrm{m}-2 \mathrm{~s}-1$ for the light period using Kessil H150 LED grow lights (Kessil Lighting, Richmond, CA).Algal populations grew at room temperature for two months, to guarantee healthy and motile organisms for the main motility study. Samples were maintained by ensuring proper medium quantity and examining the sample on a weekly basis. Nitzschia closterium (Ehrenberg) W. Smith dominated the Savannah subsamples and showed physiological activity under the conditions created in the lab, and was chosen for this study (Plate 2).

For species identification, subsamples from the Savannah River (Site 1) were inoculated with a 2:1 ratio of nitric acid to sample volume and a small concentration of potassium dichromate to dissolve organic matter. The samples were then rinsed until neutralized. Cleaned diatoms were mounted using Naphrax ${ }^{\circledR}$ (Brunel Microscopes Ltd., Chippenham, and Wiltshire, UK) on flat slides. Qualitative data were obtained by scanning a minimum of 50 fields of view under $1000 x$ magnification and documenting motile diatoms.

\section{Sediment \& Diatom Motility Assessment}

Particle-size analysis (PSA) was performed on $15 \mathrm{~g}$ of sediment from the Savannah River (Site 1). This allowed determination of the size distribution and divided into classifications of individual soil units. Soil texture is related to the mixtures of sand, silt, and clay. The United States Department of Agriculture uses a diagram known as the soil textural triangle (Figure 2) [10]. Understanding the PSA allows predicting hydraulic properties and water retention in unsaturated and saturated soils [11].

Two sediment sizes were used in this experiment: fine sand and coarse sand particles. Mud subsamples were sterilized using heat to oxidize any organic matter that may still be present. After sterilization, sediments were dried, crushed, and sieved for textural classification. Triplicate samples were prepared per sediment type. $30 \mu \mathrm{L}$ of the Savannah subsamples were placed at the bottom of a $1 \mathrm{~cm}$ cuvette and then packed with $1-2 \mathrm{~g}$ of an assigned sediment size on top. The thickness of sediment was varied experimentally between the two sites to recreate distances diatoms will have to travel if the amount of sediment in the estuary increases. Once the dried sediment was placed, the cuvettes were filled with $1 \mathrm{~mL}$ of medium. Cuvettes were also wrapped with aluminum foil to eliminate light exposure from the sides to avoid horizontal migration of the diatoms. The top of the cuvette was uncovered and exposed to light. Triplicate samples were assessed at 24hours, 72hours, and 120hours after continuous light exposure. Trial 1 had duration of 24 hours with $2 \mathrm{~g}$ of sediment. Trial 2 had duration of 72 hours with $1 \mathrm{~g}$ of sediment. Trial 3 had duration of 120 hours with $1 \mathrm{~g}$ of sediment. After the end of each trial, the top $1 \mathrm{~mm}$ of the sediment was scrapped and placed in a vile with water. This mixture was analyzed on a flat slide under LM at 400x. Approximately three slides were prepared and a minimum of 15 fields of view were analyzed per slide to qualitatively report the presence or absence of live and mobile diatoms. Average values were compared with Student's t Statistic for high and low tides or between 2011 and 2016 data.

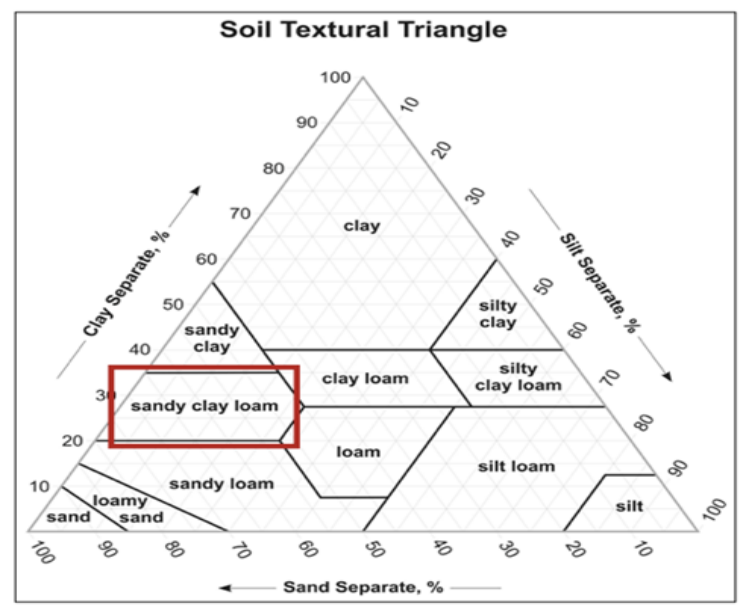

Figure 2: Soil Textural Triangle regarding the Savannah River Estuary sediment in 2016.

\section{Results}

\section{Water Parameters}

At the time of collection temperature, DO, and $\mathrm{pH}$ between high and low tide water levels were not significantly different $(\mathrm{t}$ test, $\mathrm{p}>0.05$ ).Conductivity was an order of magnitude higher at high tide conditions compared to low tide ( $t$ test, $p<0.001$, Table 1).

Comparison before and during the Savannah Harbor renovation presented that the velocity and discharge of the Savannah River have increased from 2011 to 2016. Velocity has increased from $0.1 \mathrm{~m} / \mathrm{s}$ to $0.36 \mathrm{~m} / \mathrm{s}$ during low tide. Discharge has also increased from $130.26 \mathrm{~m} 3 / \mathrm{s}$ to $427.58 \mathrm{~m} 3 / \mathrm{s}$ during low tide events. The temperature did not differ between the years and at the time of collection. Salinity decreased from $11.3 \mathrm{ppt}$ to $5.0 \mathrm{ppt}$ during high tide events (Table 2). 
Table 1: Average values and standard error for water physiochemical data of the Savannah River Estuary, Georgia during low and high tide events (Site 1).

\begin{tabular}{|c|c|c|c|c|c|}
\hline Sample & Date & Temperature $\left(\mathbf{C}^{\circ} \mathbf{C}\right)$ & Conductivity $(\boldsymbol{\mu S} / \mathbf{c m})$ & Do(mg/L) & pH \\
\hline Low Tide & $12 / 18 / 2016$ & $13.59 \pm 0.21$ & $293 \pm 20.67$ & $9.72 \pm 1.13$ & $6.70 \pm 0.07$ \\
\hline High Tide & $12 / 18 / 2016$ & $13.79 \pm 0.20$ & $3978.66 \pm 191.3$ & $7.81 \pm 0.52$ & $6.84 \pm 0.15$ \\
\hline
\end{tabular}

Table 2: Comparison of water parameters collected by USGS at site 2198920 in Port Wentworth, Georgia during high tide events during December 18, 2011 and December 18, 2016 (Site 1).

\begin{tabular}{|c|c|c|c|c|c|c|c|c|}
\hline Date & $\begin{array}{c}\text { Tide } \\
\text { Event }\end{array}$ & Velocity(m/s) & $\begin{array}{c}\text { Specific Conductivity } \\
(\boldsymbol{\mu S} / \mathbf{c m} \text { at 25-C) }\end{array}$ & Temp(-o) & Salinity(ppt) & $\begin{array}{c}\text { Discharge } \\
(\mathbf{m} 3 / \mathbf{s})\end{array}$ & DO(mg/L) & $\mathbf{p H}$ \\
\hline $12 / 18 / 2011$ & Low & 0.1 & 425 & 13.5 & 0.2 & 130.26 & - \\
\hline $12 / 18 / 2011$ & High & -0.15 & 19,000 & 14 & 11.3 & -308.65 & - & - \\
\hline $12 / 18 / 2016$ & Low & 0.36 & 110 & 12.4 & 0 & 427.58 & 9.2 & 6.9 \\
\hline $12 / 18 / 2016$ & High & -0.12 & 8920 & 13.2 & 5 & -250.32 & 6.1 & 7.4 \\
\hline
\end{tabular}

*data derived from USGS water database for the nation

\section{Sediment Analysis}

Using the soil textural triangle, the sediment from the Savannah River Estuary was classified as sandy clay loam (Figure 2). Silt/clay only provided $24 \%$ of the total dried sediment sample, whereas fine sand provided $76 \%$ of the total dried sediment. This soil type typically has a higher percentage of fine sand, which was expected due to the location of the sample site (on the coast and below the fall line of GA). Particle sizes did not overlap as to fine and coarse sediment used in the study (Table 3).

\section{Motile Diatom Community Assessment of the Savan- nah River Estuary}

In this study, 11 pennate diatoms were documented and identified to the lowest taxonomic level (Plate 1). Although there were many more species within the sample, these specimens were presented to show a broad range in species composition and diatoms that are capable of moving upwards through mudflats. The sizes of motile diatoms varied from less than 10 to $250 \mu \mathrm{m}$ and representatives from those populations were comparable to the particle sizes in our experiment. All authorities and identification references are shown in (Table 5). These 11 diatoms are described as follows:
Table 3: Sediment size data and textural classification data regarding subsamples taken from the Savannah River (Site1).

\begin{tabular}{|c|c|c|c|}
\hline $\begin{array}{c}\text { Sediment } \\
\text { Sieve }\end{array}$ & $\begin{array}{c}\text { Sediment } \\
\text { Diameter Size } \\
(\boldsymbol{\mu m})\end{array}$ & Weight (g) & Percentage (\%) \\
\hline Fine Sand & $63-250$ & 11.64 & 76 \\
\hline Silt/Clay & $<2-63$ & 3.72 & 24 \\
\hline
\end{tabular}

- Cylindrotheca gracilis, lanceolate shaped valve with helical raphes on spirally twisted frustules, no central area, ends cuneate, $65 \mu \mathrm{m}$ long, $4.4 \mu \mathrm{m}$ wide, 21 fibulae in $10 \mu \mathrm{m}$. Reported from marine environments [12,13], dominated mudflat communities in the 2011 collection and rare in the 2016 communities [8].

-Fallacia subforcipata, ovate shaped valve with broadly round poles. Coarse striae that radiate throughout, axial area inflated, straight raphe, small central area. The thin lyre-shaped lateral sterna are convex and strongly constricted centrally outlining 'the number 8,15 $\mu \mathrm{m}$ long, $7 \mu \mathrm{m}$ wide, 16 striae in $10 \mu \mathrm{m}$. Reported from marine environments, rare in epipelic samples [12,13].

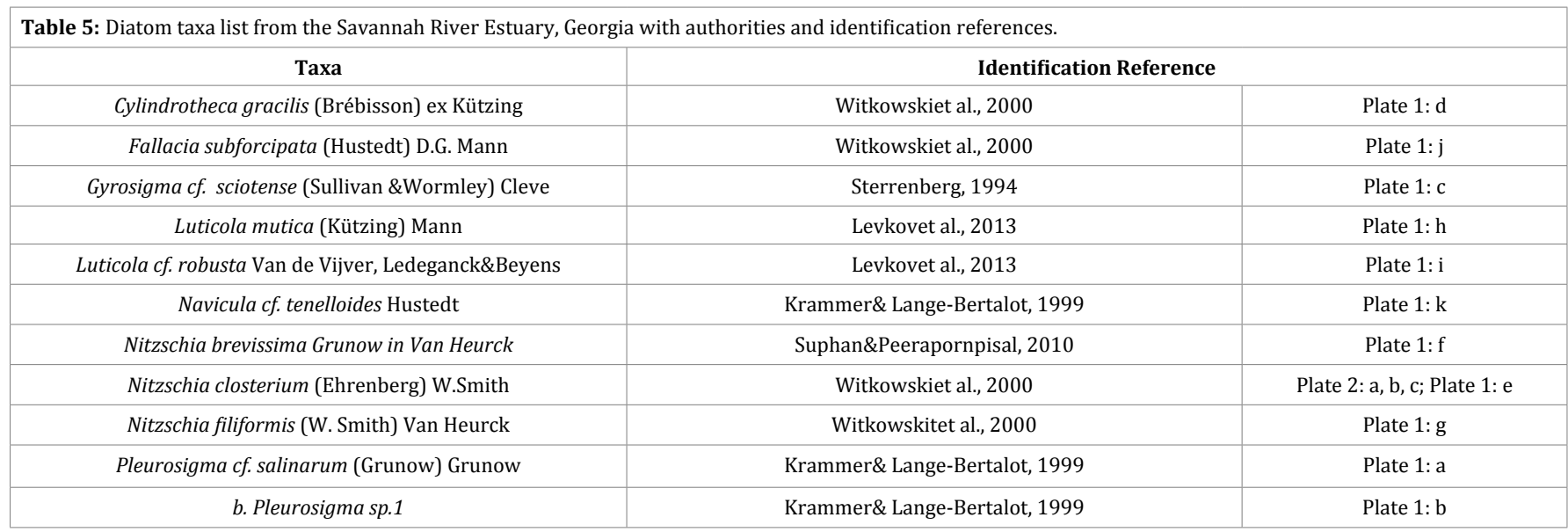


-Gyrosigma $c f$. sciotense, lanceolate-sigmoid shaped valve with middle faintly inflated, terminal fissures deflected outwards, punctae of rectangular shape, central area wide and covered by irregularly spaces punctae, $86 \mu \mathrm{m}$ long, $13.6 \mu \mathrm{m}, 22$ transverse striae, 24 longitudinal striae. Reported from freshwater environments and this species is known to flourish during winter $[12,14]$

- Luticola cf. robusta, rhombic shaped valve with broadly obtuse apices, axial area narrow, transversally elliptic central area surrounded by shortened radial striae consist of denser areolae than in the L. robusta, proximal raphe ends weakly hooked in the same direction, stigma looks more isolated (not associated with marginal areolae), $38 \mu \mathrm{m}$ long, $13.5 \mu \mathrm{m}$ wide, 10 striae in $10 \mu \mathrm{m}$. Reported from freshwater environments $[12,15]$.

-Luticola mutica, valve elliptical with broadly obtuse apices, striae radiate throughout, comprised of distinct punctae, central raphe endings very slightly deflected in one direction and distal raphe ends deflected in opposite direction, peripheral row of pores visible around the valve margin, isolated pore on one side of the transverse hyaline fascia positioned away from the valve mantle. Fascia outlined by a row of coarser punctae, somewhat symmetric, $14 \mu \mathrm{m}$ long, $6 \mu \mathrm{m}$ wide, 17 striae in $10 \mu \mathrm{m}$. Reported from brackish environments $[12,15]$.

-Navicula $c f$. tenelloides, lanceolate-narrow shaped valve, striae strongly radiate at the center, convergent near the apices, with an abrupt change in orientation about halfway along the raphe. Central striae more widely separated than close to the apices, raphe slit in a narrow axial area that widens slightly at the center to form an elliptical to narrowly rhombic central area, proximal raphe ends slightly expanded and close together, $27 \mu \mathrm{m}$ long, $5.9 \mu \mathrm{m}$ wide, 12 striae in $10 \mu \mathrm{m}$. Our specimen was longer than literature sources. Reported from freshwater to brackish environments $[12,16]$.

- Nitzschia brevissima, linear shaped valve which concave slightly towards the middle with cuneate ends, $48 \mu \mathrm{m}$ long, $8.9 \mu \mathrm{m}$ wide, striae visible in LM, but hard to count, 5 fibulae in $10 \mu \mathrm{m}$. Reported benthic in fresh and brackish waters [12,17].

-Nitzschia closterium, linear shaped valve with arcuate spines, $53 \mu \mathrm{m}$ long, $4 \mu \mathrm{m}$ wide, 15 fibulae in $10 \mu \mathrm{m}$, striae invisible under
LM. Reported from marine environments [12,13]. N. closterium was the dominant diatom species within the algal community used in the motility experiment.

- Nitzschia filiformis, lanceolate-narrow shaped valve with slightly rostrateapices that are sigmoid, raphe system 'nitzschioid,' marginal throughout, but deflected slightly inwards at the center. Central pair of fibulae more widely separated than the others forming a 'gap.' Tube dwelling diatom, motility within mucilage with high abundance in some samples, $39 \mu \mathrm{m}$ long, $5 \mu \mathrm{m}$ wide, 8 fibulae in $10 \mu \mathrm{m}$. Striae visible in LM, but difficult to count in our specimen $36 / 10 \mu \mathrm{m}$ throughout. Reported from brackish environments $[12,13]$.

-Pleurosigma cf. salinarum, lanceolate-sigmoid shaped valve with narrowed axial ends, $98 \mu \mathrm{m}$ long, $14 \mu \mathrm{m}$ wide, 24 diagonal striae, 22 transverse striae; crossing at a $62^{\circ}$ angle. Reported from marine and brackish environments $[12,16]$. Pleurosigma cf. angulatum (Quekett) W. Smith was considered for that specimen, but no literature source included the breadth of our specimen. After considering several options, our specimen is probably a new species.

-Pleurosigma sp.1, lanceolate-sigmoid shaped valve with narrowed axial ends, $80 \mu \mathrm{m}$ long, $16.6 \mu \mathrm{m}$ wide, 23 diagonal and transverse striae; crossing at a $115^{\circ}$ angle. Our specimen does not fit available literature and is probably a new species.

\section{Diatom Motility Analysis}

Nitzschia closterium was classified as a marine biraphid diatom. This taxon was documented alive and mobile in all samples inoculated in medium and had the highest relative abundance in the observed communities. Other algae that were present were green flagellate unicellular algae (Plate 2). Trail 1 had duration of 24hours underneath continuous growth light. Each cuvette contained $2 \mathrm{~g}$ of sediment in each triplicate. After the 24 hour interval, surface scrapings contained no live diatoms, which gave arise to Trial 2 to increase the length of time in which the samples were under a growth light and to decrease the amount of sediment in each cuvette (Table 4).

Table 4: Motility data in relation to sediment type, sediment amount, and duration. Contain averaged data from triplicates from all three trials.

\begin{tabular}{|c|c|c|c|c|}
\hline Sediment Type & Amount of Sediment (g) & Date Conducted & $\begin{array}{c}\text { Duration of Session } \\
\text { (hours) }\end{array}$ & Live Diatoms Present (\%) \\
\hline Coarse Sand & 2 & $3 / 30 / 2017$ & 24 & - \\
\hline Fine Sand & 2 & $3 / 30 / 2017$ & 24 & - \\
\hline Coarse Sand & 1 & $4 / 2 / 2017$ & 72 & - \\
\hline Fine Sand & 1 & $4 / 2 / 2017$ & 72 & - \\
\hline Coarse Sand & 1 & $4 / 8 / 2017$ & 120 & - \\
\hline Fine Sand & 1 & $4 / 8 / 2017$ & 120 & - \\
\hline
\end{tabular}



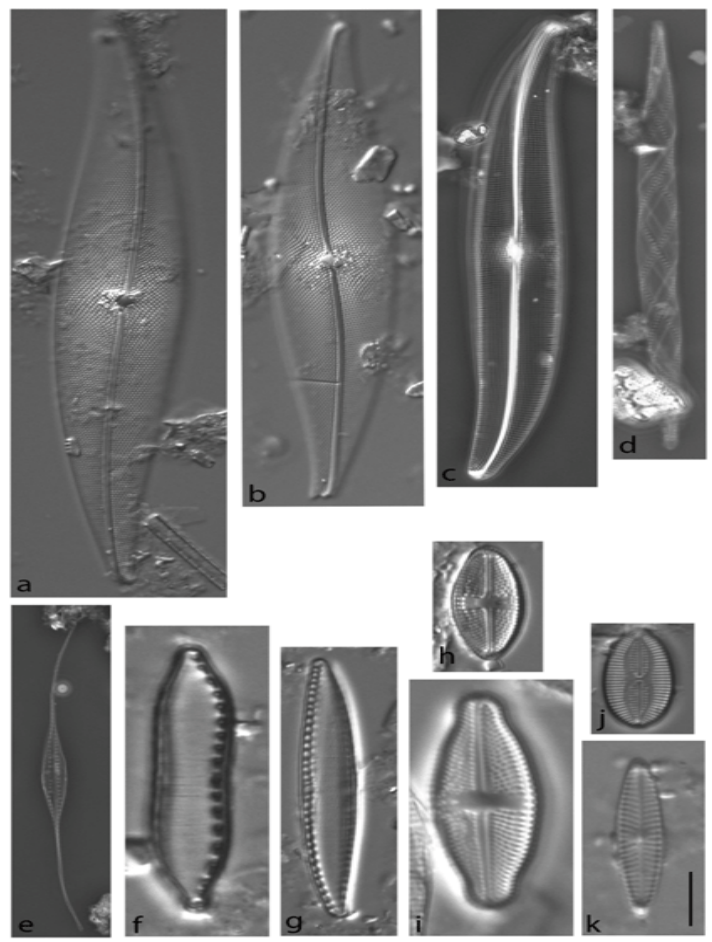

Plate 1: Cleaned diatoms of the Savannah River Estuary, Georgia. a. Pleurosigma cf. salinarum (Grunow) Grunow, b. Pleurosigma sp.1, c.Gyrosigma cf. sciotense (Sullivan \& Wormley) Cleve, d. Cylindrotheca gracilis (Brébisson) ex Kützing, e. Nitzschia closterium (Ehrenberg) W. Smith, f. Nitzschia brevissima Grunow, g. Nitzschia filiformis (W.Smith) Van Heurck, h. Luticola mutica (Kützing) Mann, i. Luticola cf. robusta Van de Vijver Ledeganck \& Beyens, j. Fallacia subforcipata (Hustedt) D.G. Mann, $k$. Navicula cf. tenelloides Hustedt. Scale bar $=10 \mu \mathrm{m}$.

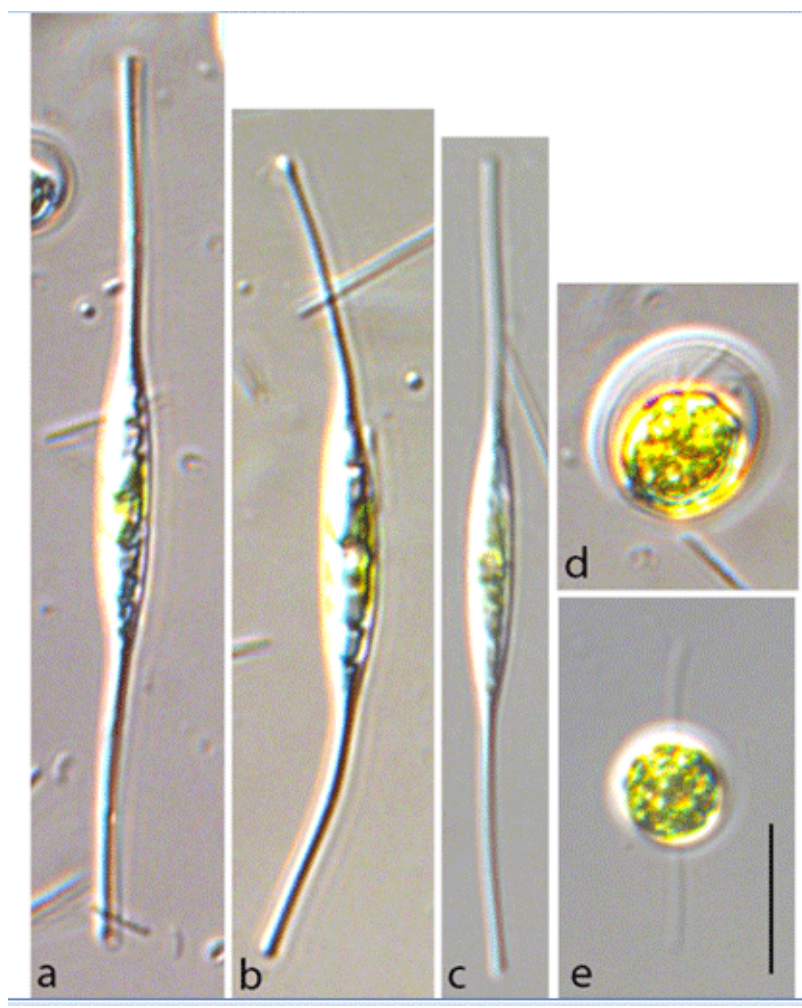

Plate 2: Live motile algal community from the Savannah River Estuary, Georgia from subsamples that were inoculated with medium. a-c. Nitzschia closterium. d-e. Green unicellular flagellates. Scale bar $=10 \mu \mathrm{m}$. 
A total of 72 hours of continuous light from a growth light was implemented on the sediment samples. Sediment quantity was decreased from $2 \mathrm{~g}$ to $1 \mathrm{~g}$ to reduce the total distance from the bottom of the cuvette to the surface. Even after the 72 hours duration of the experiment, no live diatoms were present on the surface of the cuvettes. Trial 3 had the same amount of sediment as Trial $2(1 \mathrm{~g})$, but the duration of the experiment increased to 120 hours of continuous light. Live diatoms were absent from the surface scrapping of both sediment types (Table 4).

Although each trial showed no vertical migration of motile benthic diatoms, observations of the cuvettes were documented after the end of each test. Sand samples showed evident air bubbles within the sediment, which potentially indicated high rate of photosynthesis of the living diatom community. Sand samples also showed a noticeable yellow-brown tint at the bottom of the cuvette, which reveals the presence of a fucoxanthin-rich diatom community (Figure 3).

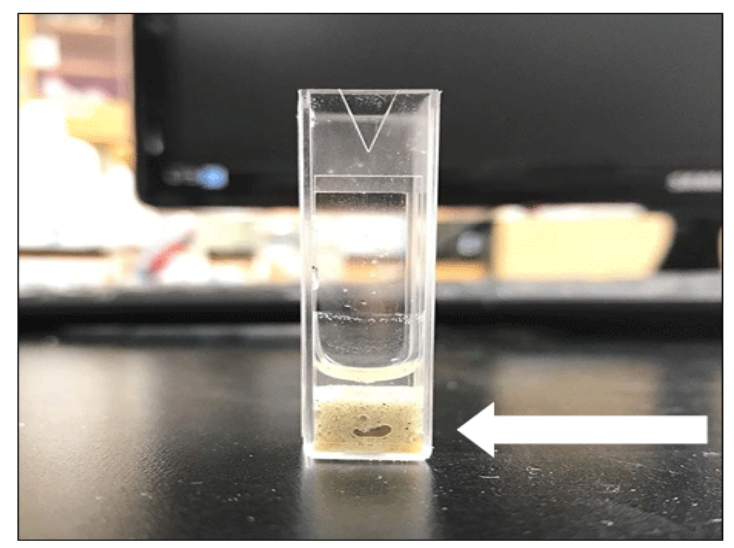

Figure 3: Observation after 120 hours under growth light. Air pockets visible and diatom sample (yellow coloring) still evident on the bottom of a $1 \mathrm{~cm}$ cuvette.

\section{Discussion}

The reasons why diatoms move to the surface of mud or sand at low tides could be due not only to access light but also to retain moisture and maintain photosynthetic activity within a mucilage biofilm. The size of the effects in natural environments, where a river flows towards the ocean and countercurrent saline waters flow upstream in the estuary, were probably necessary to trigger motility in diatoms when removed at low tide. In nature, microalgae will be dispersed within the water column, inactively following hydrologic movements. Being similar particle size in the water column, diatoms might be pressed under meters of water at high tide. As the water will be settling driven by gravity, diatoms will be additionally pressed by particles and sedimentation. When saline water retrieves during low tide, salinity pressure might be removed, and freshwater riverine environment could be a desirable environment that will stimulate vertical movements. As algae were grown for several months to increase population numbers, individuals potentially adapted to lower water pressures. The prolonged adaptation, which prevented diatoms from moving vertically during this experiment, has been suggested before [18]. Potentially several generations living within the luxurious light and nutrient conditions acclimated and did not move when the light was provided only in one direction towards a light source.

Diatom movement to the surface of sediments has been widely discussed, but no universal pattern has been concluded due to the various findings of several experiments. Many studies have suggested that tidal patterns heavily influence the migration of these organisms. As the high tide rises, the surrounding estuarine mud is fully submerged by water. Depending on the turbidity and velocity of the water, the diatom community, and its ability to photosynthesis could be affected. The increased turbidity, due to high silt deposition, could decline light quantity and quality to the photosynthetic organisms. Some studies have shown downwards benthic diatom migration due to the tidal force [1]. Diatom migration has mostly been observed during low tide, where the tidal zone is exposed to sunlight. It is understood that cells travel to the surface during daylight hours when the tide has receded, photosynthesize at the high rate and accumulate reserves at a very fast rate so they can endure high tide with no light availability. During high tide events, diatoms will use stored material, mostly glucan, chrysolaminarin, volutin, or poly phosphates for energy [2].

Diatom migration has been observed in an artificial lab setting in previous studies, in which vertical movement was successful. A study conducted by Faure-Fremiet observed the species Hantzschia amphioxys (Ehrenberg) Grunow, where tidal migration rhythms existed without the presence of a tide [19]. The migratory rhythms continued with the absence of environmental clues for a certain amount of time, but after several days the migration halted. This is significant due to the fact, that vertical migration is possible in an artificial environment.

Considering the light conditions, diatoms are also known to be affected by the light quantities and light quality. The continuous light was exposed to the samples to allow opportunities for the diatoms to move to the surface to perform photosynthesis. A study conducted by Round found that benthic diatom; Tropidoneis lepidoptera Gregory (Cleve), under constant light adopted a diurnal migratory pattern, regardless of the tide schedule [20]. Other factors could have acted as stimuli. All collections of algae were performed at low tide conditions, but the alterations of conductivity diurnally between high and low tide conditions could have been a stimulus that cannot be recreated in lab conditions.

Several studies have shown that diatoms emerge to the surface only during the day, which is indicated by maximum light coverage. Although light is vital, the biological clock hypothesis has been tested, which entailed the idea of diatoms possessing a circadian rhythm that synchronizes the migration of motile diatoms at certain times [18]. These patterns could be related to the shifts in high to low tide and light to dark environments [1].

The increase in the hydraulic mixing of freshwater and salt water, from the increase of stream velocity and discharge, could be an explanation for the decrease of salinity over time (Table 2). Temperature, $\mathrm{DO}, \mathrm{pH}$, and conductivity readings may differ 
between the YSI interpretations (Table 1) and USGS water data (Table 2), due to the location of the probes. YSI data was collected on the perimeter of the estuary, whereas the USGS collection site is located in the water column offshore.

Fluctuations of salinity are a known factor that affects mobilization of benthic diatoms. Due to the significant decrease in salinity in the Savannah River, this could also be a plausible explanation in why diatoms did not migrate during the lab experiment (Table 2). Many epipelic and epipsammic diatom species are found in estuaries where water parameters are constantly changing, especially salinity and conductivity. From previous studies suggest that in mudflat habitats, seasonal and spatial patterns affect the spatial patterns of these organisms. This implies that epipelic and epipsammic diatoms may prefer particular niches [21].

Another study concluded that the fluctuating salinities do not affect the process of photosynthesis of estuarine diatoms [22]. In estuaries, the influx of salinity is brought in by high tide events. With the increase in stream velocity and total discharge, there is a greater potential of more nutrients to be implemented or eliminated (Table 2). Ammonium, in particular, is an important component in influencing the distribution of benthic diatoms in mudflats [23]. There are specific species that have a higher tolerance for increased concentrations of ammonia, like Nitzschia sigma and Cylindrotheca gracilis, which are found in the Savannah River Estuary [8, 24, 25]. There are very few studies conducted on the ammonia tolerance on Nitzschiaclosterium. It can be proposed that $N$. closterium did not vertically migrate due to the nutrient concentrations in the lab. The medium used contained sodium nitrate, disodium phosphate, and vitamin $B_{12}$ [26].

A study conducted by Suburova and Polikarpov suggested that downward migration may be caused by the response of nutrient and $\mathrm{CO}_{2}$ levels. With low nutrient levels on the surface, diatoms may migrate further into the sediment to obtain these vital nutrients. There is a more favorable environment for the diatoms to enhance growth and proceed with cell division since there are more reduced forms of nitrogen that are available [27]. $\mathrm{CO}_{2}$ and nutrient data was not gathered for this study.

Taxonomic identification of the diverse coastal community remains important. In this study, routine LM observations provided limited morphological data and species name assignments were not possible. Taxonomic work continues using scanning-electron microscope at GCSU for further floristic work, which was not the objective of this study. Sediment collected from the 2 locations was successfully utilized by motile diatoms in the field. The mobile diatom assessment provided evidence that motile diatoms are present in the Savannah River Estuary mudflats and are capable of vertical movement. Graduate research on the Savannah River mudflats continues, where "live" diatoms at the time of collection are being documented. live to dead diatom ratios have been very important for estuarine mudflat diatoms [8]. "Live" diatoms are indicated when physiologically active chloroplasts are present, where photosynthesis is occurring. The total diatom community is being dominated by diatoms that do not contain any chloroplasts or other organelles, which are classified as "dead" diatoms. This indicates that there are many diatoms that are being deposited already dead or diatoms are unable to surface to photosynthesize because of the heavy deposition of fine sediments.

\section{Conclusion}

This research is one of the few studies on the ecology of benthic diatoms, including estuarine brackish and marine species. Loose vs. packed sediment in small quantities may have contributed to the lack of migration in both fine sand and sand sediments. With the decrease of the area between the grains, the diatoms may have been restricted to potential pathways to reach the surface. In addition to the compaction of the sediment, excessive shading within the sediment may have prevented diatom motility. Although the light was continuously available, the foil coverage, small total surface area of the $1 \mathrm{~cm}$ cuvette, and heavy sediment compaction could have hindered the potential of vertical migration.

Although tidal and light patterns have been implied by many studies to be the main contributors of vertical migration, the Faure-Fermiet [19] study is an example of diatom movement in an artificial environment within a laboratory setting. In future experiments, light patterns will be applied as well as lighter compaction of sediment. Future studies will conclude if sediment size can negatively affect vertical migration and this study will be related to the overall health and change within the Savannah River. Taxonomic work will be continued, which will involve a complete community assessment on the Savannah River Estuary, scanning-electron microscopy analysis, and description of new to science taxa.

\section{Acknowledgements}

We would like to thank Jenna Forte for helping with the field collection and Shelly Wu for helpful discussion on species identification within the genus Luticola. We are thankful to Dr. Mary Skopec and the Friends of Lakeside at Iowa Lakeside Laboratory for awarding a visiting research scholarship to Alyssa Thomson. This work was part of the first author's Masters graduate research at the Department of Biological and Environmental Sciences at Georgia College and State University. This work was supported by the Department of Biological and Environmental Sciences and the Graduate School at Georgia College and State University.

\section{References}

1. Consalvey M, Paterson D, Underwood GJC. The ups and downs of life in a benthic biofilm: migration of benthic diatoms. Diatom Research. 2004;19(2):181-202.

2. Round FE, Crawford RM, Mann DG. The Diatoms: Biology \& Morphology of the Genera. New York: Cambridge University Press; 1990.

3. Apoya-Horton MD, Yin L, Underwood GJC, Gretz MR. Movement modalities and responses to environmental changes of the mudflat diatom Cylindrotheca Closterium (Bacillariophyceae). Phycological Society of America. 2006;42(2):379-390.

4. Frankenbach S, Pereira CP, Martinez M, Laviale M, Ezequiel J, Serodio 
J. Evidence for gravitactic behaviour in benthic diatoms. Eur J Phycol. 2014;49(4):429-435. doi:10.1080/09670262.2014.974218

5. Flemming HC, Wingender J. The biofilm matrix. Nat Rev Microbiol. 2010;8(9):623-633. doi: 0.1038/nrmicro2415

6. US Army Corps of Engineers. What is the SHEP? 2017.

7. Jones JI, Duerdoth CP, Collins AL, Naden PS, Sear DA. Interactions between diatoms and fine sediment. Hydrological Processes. 2014;28(3):1226-1237. doi:10.1002/hyp.9671

8. Manoylov KM, Dominy JN. Changes in epipelic diatom diversity from the Savannah River Estuary. Journal of Environmental Protection. 2013;4(2):172-179.

9. APHA. Standard Methods for Examination of Water and Wastewater 20th ed. Washington DC: American Public Health Association; 1998.

10. Natural Resources Conservation Service. Soil Textural Triangle. 2017.

11.Gee GW, Or D. Particle Size Analysis. In: Dane JH, Topp GC, editors Methods of Soil Analysis, Part 4, Physical Methods. Madison: Book Series No. 5, Soils Science Society of America; Madison: 2002. P. 255293.

12.Guiry MD, Guiry GM. Algae Base. World-wide electronic publication National University of Ireland, Galway. 2013

13.Witkowski A, Lange-Bertalot H, Metzeltin D. Lange-Bertalot H, editor Diatom Flora of Marine Coasts I. Koeltz Scientific Books; 2000.

14.Sterrenburg FAS. Studies on the Genera Gyrosigma and Pleurosigma (Bacillariophyceae). Proceedings of the Academy of Natural Sciences of Philadelphia. 1994;145:217-236.

15. Levkov Z, Metzeltin D, Pavlov A, Bertalot HL. Luticola and Luticolopsis. In: Diatoms of Europe. Diatoms of the European inland waters and comparable habitats. Königstein: Koeltz Scientific Books; 2013. p.1698.

16. Krammer K, Lange-Bertalot H. Süßwasserflora von Mitteleuropa, Bd 02/1: Bacillariophyceae, 1. Teil: viculaceae, A: Text; B: Tafeln. Springer Spektrum. 1999.
17. Suphan S, Peerapornpisal Y. Fifty-Three New Record Species of Benthic Diatoms from Mekong River and Its Tributaries in Thailand. Chiang Mai J Sci. 2010;37(2):326-343.

18. Round FE, Palmer JD. Persistent, vertical-migration rhythms in benthic microflora: II. Field and Laboratory Studies on Diatoms from the Banks of the River Avon. Journal of the Marine Biological Association of the United Kingdom. 1966;46(1):191-214.

19. Faure-Fremiet E. The Tidal Rhythm of the Diatom Hantzschia Amphioxys. Marine Biological Laboratory. 1951; 100(3):173-177.

20. Round FE. Occurrence and rhythmic behaviour of Tropidoneis Lepidoptera in the epipelon of Barnstable Harbor, Massachusetts, USA. Marine Biology. 1979;54(3):215-217.

21. Underwood GJC, Phillips J, Saunders K. Distribution of estuarine benthic diatom species along salinity and nutrient gradients. European Journal of Phycology. 1998;33(2):173-183.

22. Admiraal W, Peletier H. Distribution of diatom species on an estuarine mud flat and experimental analysis of the selective effect of stress. Journal of Experimental Marine Biology and Ecology. 1980;46(2):157175

23. Peletier $H$. Long-term changes in intertidal estuarine diatom assemblages related to reduced input of organic waste. Marine Ecology Progress Series. 1996;137:265-271.

24. Underwood GJC, Smith DJ. Predicting Epipelic Diatom Exopolymer Concentrations in Intertidal Sediments from Sediment Chlorophyll a. Microbial Ecology. 1998;35(2):116-125.

25. Underwood GJC, Provot L. Determining the environmental preferences of four estuarine epipelic diatom taxa: growth across a range of salinity, nitrate and ammonium conditions. European Journal of Phycology. $2000 ; 35(2): 173-182$

26. UTEX. Erdschreiber's Medium. 2017.

27. Saburova MA, Polikarpov IG. Diatom activity within soft sediments: behavioural and physiological processes. Marine Ecology Progress Series. 2003;251:115-126. doi:10.3354/meps251115 